\title{
Evaluation of Fungicides to Control Asian Rust and Anthracnose in Soybean
}

\author{
Nathan Guilherme Lima Pereira, Nathan Canezin Martins, Julliane Destro Lima \\ Paranaense University, Umuarama, Paraná, Brazil
}

\begin{abstract}
Éder Blainski
Terra Paraná Pesquisa e Treinamento Agrícola Ltda. LR 180, 181 e 182, Gleba Silveira, Zip: 85935-000, Assis Chateaubriand/Paraná, Brazil
\end{abstract}

Marcelo Berwanger de Oliveira

Fundação Assis Gurgacz, Cascavel, Paraná, Brazil

Daniele Cunha Cardoso

Universidade Federal de Minas Gerais, Belo Horizonte, Minas Gerais, Brazil

Glacy Jaqueline da Silva

Paranaense University, Brazil

Received: August 1, 2019 Accepted: Sep. 2, $2019 \quad$ Published: Sep. 6, 2019

doi:10.5296/jas.v7i4.15178

URL: https://doi.org/10.5296/jas.v7i4.15178

\begin{abstract}
Soybean (Glicine max L.) is one of the most important crops from the economic standpoint for Brazil and due to the favorable climate for the development of fungal diseases, requires special needs. The fungal diseases with the greatest economic impact on Brazilian culture are Asian rust, caused by the fungus Phakopsora pachyrhizi and Anthracnose, caused by Colletotrichum truncatum. Together, without proper control, they can be devastating. Fungicides represent a high cost to producers, however, necessary for productivity losses do not decrease production. In this way, obtaining a combination of fungicides that provides results for the control of the diseases, from the beginning of the infestation period, with a
\end{abstract}


satisfactory cost benefit is of the utmost importance to Brazilian producers. The objective of this study was to evaluate the combination of six commercial fungicides (APROACH PRIMA $^{\circledR}$, SPHERE MAX ${ }^{\circledR}$, FOX $^{\circledR}$, FUSÃO $^{\circledR}$, ELATUSTM and ORKESTRA) and sequential applications in the control of anthracnosis and asian rust at the soybean cultivar "Monsoy 5947 IPRO"; besides establishing the best cost benefit for the application of these fungicides. The results show that all evaluated treatments presented statistically significant result, and suggest the use of Orkestra ${ }^{\circledR} /$ Aproach Prima ${ }^{\circledR} /$ Sphere Max $^{\circledR}$ fungicides in sequential applications for the control of Asian rust and anthracnose in the region of Assis Chateaubriant, Paraná, Brazil.

Keywords: colletotrichum truncatum, commodity, disease control, Glicine max L., Phakopsora pachyrhizi

\section{Introduction}

Soybean (Glycine $\max$ (L.) Merrill) is one of the most valuable crops in the world, and it is extremely important for the production of oil and protein content (Food and Agriculture Organization of the United Nations [FAO], 2019). There is a great growth estimate of this commodity worldwide, and researchers spare no efforts to increase production gains, mainly by reducing disease-related losses. Some examples of this are the great number of studies that evaluate strategies to control these related diseases, as potassium silicate ( $\mathrm{KSi}$ ) spray to reduce the intensity of soybean rust in greenhouse and in the field (Rodrigues et al. 2009); the use of Bacillus spp. and coffee oil, alone and combined with fungicides to inhibit the germination of P. pachyrhizi (Doringuello et al. 2015); combination of fungicides to control Anthracnose (Basso et al. 2015).

Asian soybean rust (ASR), caused by Phakopsora pachyrhizi (Goellner, et al. 2010), and anthracnose, caused by Colletotrichum truncatum (Yang \& Hartman, 2015), are the two diseases that cause major economic impact on soybean crops.

Under favorable conditions for both diseases, the loss estimate can be severe (Sharma, et al. 2011; Klosowski, et al. 2016; Moura, et al. 2016), and these losses mean a lot of money in large producing countries. In 2006, the 8 most producing countries in the world had a productivity loss of 2539600 tons, caused by anthracnose, and 13239000 tons caused by ASR. An US data survey concluded that from 2006 to 2009, in 28 evaluated states, there was a yield loss of 57073000 hectares of soybean caused by anthracnose, and 4561000 hectares caused by ASR (Koenning \& Wrather, 2010).

In Brazil, the Cerrado is the most affected region by both ASR and Anthracnose, since the environment makes this crop susceptible to infection (Ito, 2013). However, dramatic losses have been recorded in several regions.

Although ASR has only been introduced in Brazil recently, it was first reported in 2001 (Rossi, 2003) when intense epidemics had been recorded in Mato Grosso State, shortly after its introduction into Brazil, with estimated losses of US \$ 487 million, without considering of the cost with fungicides, which had to be applied twice at a cost of US \$544 million 
(Yorinori et al, 2005). In the northern region of Brazil, losses of $90 \mathrm{~kg} \mathrm{ha}^{-1}$ of soybean were reported with $1 \%$ increase in the incidence of anthracnose (Dias, et al. 2016).

One of the strategies to control these diseases is the use of fungicides (Pesqueira, et al. 2016; Sacon, et al. 2018). Fungicides are a class of agricultural pesticides that are essential for the effective control of plant diseases (Reis et al, 2014). Currently, soybean cultivated with disease control through the application of fungicides reaches 33.7 million hectares totaling 11 applications in more extreme cases such as in the second soybean harvest (small harvest). Due to the enormous amount of applications, pathogen resistance to fungicide treatment is a serious and intensively studied problem in the management of various diseases in many crops (Balardin, et al. 2017). Soybean cultivation requires sequential fungicide applications to protect against shoot diseases.

Fungicides are classified according to their chemical function (traditionally known in the market) and their action mechanism. The current classification of soybean fungicides comprises three classes: triazoles (DMI), strobilurins (Qol) and carboxamides (SDHI) to which certain pathogens have already been reported to be resistent (Fungicide Resistance Action Committee [FRAC], 2018).

Choosing which diseases to control becomes a challenge every harvest due to the fungus resistance against the implemented treatment. This is mostly caused by producers' negligence, support technicians' lack of information or initiative regarding the integrated management of diseases and application programs to avoid the use of agrochemicals against absurdly high fungal populations, besides applying fungicides without thoroughly analyzing the infecting pathogen, and with replicates of the same action mechanism or active ingredients (FRAC, 2018).

Considering the disease selection pressure due to unrestricted use of fungicides, there has been a search for a fungicide combination that best meets commercial and field recommendations to effectively control plant pathogens. Thus, diseases could be controlled preferably from the infestation onset, preventing the gradual increase in their insensitivity. Therefore, this research study aimed to verify the best available fundicide combinations for the western region of Paraná state in Brazil, and to combine their action mechanisms, using the commercial recommendation for each active ingredient, for different associations and application periodsin the soybean crop.

\section{Material and Methods}

The experiment was carried out at Terra Paraná Pesquisa e Treinamento Agrícola Ltda, located in the Rural Lots 180, 181 and 182 at Gleba Silveira in the city of Assis Chateaubriand,Pr, Brazil, under coordinates $24^{\circ} 17^{\prime} 35.16^{\prime}$ 'S; 53⒊'47.02' 'W and altitude of $326 \mathrm{~m}$.

"Monsoy 5947 IPRO" cultivar was used. Seeding was done on October 14, 2017, considering the distribution of 15 seeds per linear meter. The industrial treatment was based on Standak Top (Fipronil + Piraclostrobina) and basic fertilization of $250 \mathrm{~kg} / \mathrm{ha}$ of the formulated NPK 02-20-18. Weed control was done with Roundup Ready herbicide $\left(2.0 \mathrm{~L}^{-h^{-1}}\right)$, when the crop 
was still in the vegetative stage. Bugs and caterpillars that could cause economic damages to the crop were controlled at the beginning of each application with Engeo Pleno ${ }^{\mathrm{TM}}$ (200 $\left.\mathrm{ml} / \mathrm{ha}^{-1}\right)$ and Premio ${ }^{\circledR}\left(50 \mathrm{ml} / \mathrm{ha}^{-1}\right)$.

The experimental design had randomized blocks with 7 treatments and 4 replicates. The experimental plots were 3.5 meters wide and 6 meters long. The fungicide applications were carried out in post-emergence phase, specifically in the reproductive phase (R1, R1+15 days and $\mathrm{R} 1+30$ days), with a standard volume of $200 \mathrm{~L}^{-h^{-1}}$ per application and with constant pressure costal sprayer based on $\mathrm{CO}_{2}$, equipped with 6-nozzle application bar, type fan XR-110.02 and pressure of $2.0 \mathrm{kgf.cm}{ }^{-2}$.

For the applications, six fungicides were selected, according to field research in the region of Assis Chateaubriand, PR, Brazil, considering their wide use in the last harvests and their productivity results. The utilized fungicides were classified by their formulation with 4 DMI + Qol (triazoles and strobilurins), and 2 Qol + SDHI (strobilurin + carboxamide), and they were: APROACH PRIMA $^{\circledR}$ (Cyproconazole + Picoxystrobin); SPHERE MAX $^{\circledR}$ $\left(\right.$ Cyproconazole + Trifloxystrobin); FOX $^{\circledR}$ (Prothioconazole + Trifloxystrobin); FUSÃO ${ }^{\circledR}$ (Tebuconazole + Metominostrobin); ELATUSTM (Azoxystrobin + Benzovindiflupir) and ORKESTRA $^{\circledR}$ : (Piraclostrobin + Fluxapiroxade). The dosages, composition of each treatment and phenological stage of the crop at the application time are presented in Table 1.

Table 1. Treatments used to evaluate the control of P. pachyrhizi and C. truncatum in 3 sequential applications

\begin{tabular}{clll}
\hline Treatment & Application 1 (R1) & Application 2 (R1+15) & Application 3 (R1+30) \\
\hline 1 & Control & Control & Control \\
2 & Orkestra $\left(350 \mathrm{~mL} / \mathrm{ha}^{-1}\right)^{1 /}$ & Aproach Prima $\left(300 \mathrm{~mL} / \mathrm{ha}^{-1}\right)^{1 /}$ & Sphere Max $\left(200 \mathrm{~mL} / \mathrm{ha}^{-1}\right)^{2 /}$ \\
3 & Fox $\left(400 \mathrm{~mL} / \mathrm{ha}^{-1}\right)^{2 /}$ & Aproach Prima $\left(300 \mathrm{~mL} / \mathrm{ha}^{-1}\right)^{1 /}$ & Sphere Max $\left(200 \mathrm{~mL} / \mathrm{ha}^{-1}\right)^{2 /}$ \\
4 & Fusão $\left(600 / \mathrm{ha}^{-1} \mathrm{~mL}\right)^{1 /}$ & Aproach Prima $\left(300 \mathrm{~mL} / \mathrm{ha}^{-1}\right)^{1 /}$ & Sphere Max $\left(200 \mathrm{~mL} / \mathrm{ha}^{-1}\right)^{2 /}$ \\
5 & Elatus $\left(200 / \mathrm{ha}^{-1} \mathrm{~g}\right)^{1 /}$ & Aproach Prima $\left(300 \mathrm{~mL} / \mathrm{ha}^{-1}\right)^{1 /}$ & Sphere Max $\left(200 \mathrm{~mL} / \mathrm{ha}^{-1}\right)^{2 /}$ \\
6 & Orkestra $\left(350 / \mathrm{ha}^{-1} \mathrm{~mL}\right)^{1 /}$ & Fox $\left(400 \mathrm{~mL} / \mathrm{ha}^{-1}\right)^{2 /}$ & Aproach Prima $\left(300 \mathrm{~mL} / \mathrm{ha}^{-1}\right)^{1 /}$ \\
7 & Fox $\left(400 / \mathrm{ha}^{-1} \mathrm{~mL}\right)^{2 /}$ & Orkestra $\left(350 \mathrm{~mL} / \mathrm{ha}^{-1}\right)^{1 /}$ & Aproach Prima $\left(300 \mathrm{~mL} / \mathrm{ha}^{-1}\right)^{1 /}$ \\
\hline
\end{tabular}

1/: Added Nimbus ${ }^{\circledR} 600 \mathrm{~mL} / \mathrm{ha}-1$;

\section{2/:Added Aureo® 500 mL/ha-1;}

After the third application of the fungicide combinations, the incidence of Asian rust and anthracnose was evaluated in 30 leaves (10 trifolia) per plot, collected at random, in each of the upper, middle and lower parts of the plants. The incidence was evaluated before each application of the fungicides, and at 7, 14, 21 and 28 days after the third application (DA3TP). 
The evaluation was done through the calculation of mean values, established by the number of infested leaves in each treatment.

Disease severity was measured by assigning scores from 0 to 100 , where " 0 " is the total absence of symptoms and "100" is the presence of symptoms in the entire leaf area, using Godoy's diagrammatic scale method (2006) (Godoy et al. 2006). The Severity grades are used for the development of the Area under the disease progress curve (AUDPC) calculation by the formula AUDPC $=\{[(\mathrm{yi}+\mathrm{yi}+1) / 2 . \mathrm{dti}] / \mathrm{n}\}$; where $\mathrm{yi}$ and $\mathrm{yi}+1$ are the severity values observed at two consecutive evaluations; dti is considered the interval between the evaluations, and " $n$ " is the number of observations (Campbell \& Madden, 1990). In this calculation, each interval is added in the end and evaluated so that it is possible to measure the development of the diseases. The efficiency of fungicides in the control of diseases (EFCD) was calculated using the severity and AUDPC data, and Abbott's formula (Abbott, 1925), comparing the mean values by the Scott-Knott's test (1974) (Scott \& Knott, 1974).

The crop productivity was corrected to $14 \%$ moisture with approximately $6 \mathrm{~m}^{2}$ of harvested area (three central rows of each plot).

\section{Results and Discussion}

\subsection{Anthracnose}

The anthracnose severity data observed in the lower third of soybean leaves after 7 and 21 DA3TP are shown in Table 2. In the previous visual analysis preceeding each application, the expected visible Colletotrichum truncatum symptoms were considered non-existent (Table 2).

Table 2. Anthracnose severity data observed in the lower third of soybean leaves after 7 and 21 DA3TP

\begin{tabular}{ccccccc}
\hline Treatment & $\begin{array}{c}\text { Severity } \\
(7 D A 3 T P)\end{array}$ & $\begin{array}{c}\text { Severity } \\
(21 D A 3 T P)\end{array}$ & AUDPC & EFCD \% & $\begin{array}{c}\text { Incidence } \\
\text { (7DA3TP) \% }\end{array}$ & $\begin{array}{c}\text { Incidence } \\
(21 D A 3 T P)\end{array}$ \\
\hline 1 & $2.10^{\mathrm{d}}$ & $100^{\mathrm{c}}$ & $722.05^{\mathrm{e}}$ & 0.00 & $100^{\mathrm{d}}$ & $100^{\mathrm{b}}$ \\
2 & $0.13^{\mathrm{a}}$ & $0.3^{\mathrm{a}}$ & $3.46^{\mathrm{a}}$ & $93.81^{\mathrm{a}}$ & $67.5^{\mathrm{b}}$ & $95^{\mathrm{b}}$ \\
3 & $0.33^{\mathrm{b}}$ & $0.42^{\mathrm{a}}$ & $6.44^{\mathrm{b}}$ & $84.29^{\mathrm{b}}$ & $90^{\mathrm{d}}$ & $100^{\mathrm{b}}$ \\
4 & $0.29^{\mathrm{b}}$ & $0.93^{\mathrm{b}}$ & $9.63^{\mathrm{c}}$ & $86.19^{\mathrm{b}}$ & $80^{\mathrm{c}}$ & $100^{\mathrm{b}}$ \\
5 & $0.68^{\mathrm{c}}$ & $1.22^{\mathrm{b}}$ & $15.70^{\mathrm{d}}$ & $67.62^{\mathrm{c}}$ & $97.5^{\mathrm{d}}$ & $100^{\mathrm{b}}$ \\
6 & $0.05^{\mathrm{a}}$ & $0.10^{\mathrm{a}}$ & $1.33^{\mathrm{a}}$ & $97.62^{\mathrm{a}}$ & $37.5^{\mathrm{a}}$ & $70^{\mathrm{a}}$ \\
7 & $0.36^{\mathrm{b}}$ & $0.84^{\mathrm{b}}$ & $9.72^{\mathrm{c}}$ & $82.86^{\mathrm{b}}$ & $92.5^{\mathrm{d}}$ & $100^{\mathrm{b}}$ \\
\hline $\mathrm{F}$ & 244.83 & 118000.85 & 99 & & 37.182 & 8.51 \\
$\mathrm{CV}(\%)$ & 15.98 & 1.47 & 1.56 & & 8.97 & 8.07 \\
\hline
\end{tabular}

After the end of application, the symptoms of anthracnose symptoms could be clearly observed in the first evaluation of the lower third, where the presence of the disease was still rare, both in the witnesses and treatments. The severity level was $2.1 \%$ where there was no 
fungicide application and the severity average was $0.30 \%$ in the blocks of the performed treatments. The favorable weather conditions for disease improvement (soil moisture, relative air humidity, mild temperatures) combined with early applications for disease control in the last stage, caused an increase in the severity of anthracnose, spiking from $2.1 \%$ to $100 \%$ severity in the control block, and mean of $0.64 \%$ in the plants submitted to the treatments. The total early defoliation of the lower third of the control plants was observed, damaging grain filling and, consequently, productivity. This indicates that the fungicide application was a good strategy for disease control in the climate conditions studied.

All evaluated treatments had lower severity of Anthracnose compared to the control. However, Elatus ${ }^{\circledR} /$ Aproach Prima ${ }^{\circledR} /$ Sphere Max ${ }^{\circledR}$ obtained the worst score among fungicides and, in this case, is the least recommended control program for Colletotrichum truncatum.

Evaluating the formulation of Aproach Prima ${ }^{\circledR}$ (Ciproconazol+Picoxystrobin), Pesqueira et al. (2016) were not successful using the compound soon after the appearance of the first symptoms (R2 stage) in the susceptible Coodetec 219 RR cultivar, in the region of Dourados,MS, Brazil. This compound and a mixture of epoxiconazole + pyraclostrobin were not able to control the disease at the R5.2 stage. Although the blend of Elatus ${ }^{\circledR} /$ Aproach Prima ${ }^{\circledR} /$ Sphere Max $^{\circledR}$ of the present study obtained a lower score compared to the other treatments, it was still able to control the disease progress, unlike the research conducted by Pesqueira et al. (2016). This control may have occurred because of the diversity of compounds used in this research, hindering the proliferation of the pathogen. It may also have occurred due to the fungicide application before the onset of the first symptoms, in R1.

In a study conducted by Alves and Juliatti (2018), they confirmed that the combination of the same compounds used in this study (Piraclostrobin + Fluxapiroxade + Prothioconazole + Trifloxystrobin + Cyproconazole + Picoxystrobin) provided ample control of pathogens when added with mancozeb. In this study it was not necessary to use mancozeb for the whole pathogen population to be contained.

In relation to the AUDPC of $C$. truncatum, all the treatments obtained higher statistical values when compared to the control. Among the treatments, Elatus ${ }^{\circledR} /$ Aproach Prima ${ }^{\circledR} /$ Sphere Max ${ }^{\circledR}$ obtained scores in Godoy's scale which were very low compared to the other fungicides; Fusão ${ } /$ Aproach Prima ${ }^{\circledR} /$ Sphere Max $^{\circledR}$ and Fox ${ }^{\circledR} /$ Orkestra ${ }^{\circledR} /$ Aproach Prima ${ }^{\circledR}$ obtained statistically similar results, and presented medium to low performance in the control of anthracnose, with high values of AUDPC, followed by Fox ${ }^{\circledR} /$ Aproach Prima ${ }^{\circledR} /$ Sphere $\operatorname{Max}^{\circledR}$, with medium to high performance; Orkestra ${ }^{\circledR} /$ Fox $^{\circledR} /$ Aproach Prima ${ }^{\circledR}$ and Orkestra $^{\circledR} /$ Aproach Prima ${ }^{\circledR} /$ Sphere Max ${ }^{\circledR}$ with lower values of AUDPC and better control of the pathogen. This was a great result, because it was possible to name a great treatment regarding AUDPC and this is important when choosing the best strategy to adopt in the field. It is not always possible to choose the best treatments, especially when the field conditions for the proliferation of the pathogen are not favorable, as in the case of Basso et al. (2015), where the authors failed to observe significant differences among eight treatments with different fungicides used to control anthracnose in relation to AUDPC. 
The treatment that obtained the best efficiency in the control of $C$. truncatum was Orkestra $^{\circledR} /$ Fox $^{\circledR} /$ Aproach Prima ${ }^{\circledR}$, reaching $97.62 \%$ in relation to the control. The worst efficiency performance was Elatus ${ }^{\circledR} /$ Aproach Prima ${ }^{\circledR} /$ Sphere Max ${ }^{\circledR}$ treatment, achieving $67.62 \%$ of efficiency in relation to the control. The efficiency variation of the treatments could also be observed by Adami et al. (2006) who evaluated the efficiency of 14 fungicides in BRS 234 cultivar against anthracnose. In that study, Domark ${ }^{\circledR}$ fungicide was the most efficient but did not differ significantly from $5 \%$ of Opera 0.5 , Impact, Cercobin ${ }^{\circledR}$, Proline ${ }^{\circledR}$, Artea $^{\circledR}$, Sphere ${ }^{\circledR}$, Score $^{\circledR}$, Derosal ${ }^{\circledR}$, Opera ${ }^{\circledR} 0.6$ and Priori Xtra ${ }^{\circledR}$; but differed significantly from Nativo ${ }^{\circledR}$, Celeiro ${ }^{\circledR}$ and Cerconil ${ }^{\circledR}$ fungicides, which presented lower control results.

The incidence of anthracnose was evaluated in all canopy of plants, and symptoms were absent during the first evaluations that preceded each fungicide application. The incidence was initially observed in the lower third of the plants, considering the disease development and infestation. Applications were done preventivelly, anticipating anthracnose infestation period or before symptom manifestation period. Orkestra ${ }^{\circledR} /$ Fox $^{\circledR} /$ Aproach Prima ${ }^{\circledR}$ treatment stood out because it kept the highest level of control in relation to other treatments, and it is shown in Table 2. Low levels of infestation and severity of anthracnose have also been found by Adami et al. (2006) before the first application; therefore, fungicideapplication R1 was also considered preventive.

\subsection{Asian Rust}

Asian rust severity data were observed in all plant parts, 21 days DA3TP and 28 DA3TP, considering that in the previous 1,2 and 3 days that precede each application and in the evaluation at $7 \mathrm{DA} 3 \mathrm{TP}$ and $14 \mathrm{DA} 3 \mathrm{TP}$, there were no visible symptoms showing the incidence and severity of Phakopsora pachyrhii (Table 3).

Table 3. Asian rust severity observed in soybean plant, 21 days DA3TP and 28 DA3TP

\begin{tabular}{ccccccc}
\hline Treatment & $\begin{array}{c}\text { Severity } \\
(21 D A 3 T P)\end{array}$ & $\begin{array}{c}\text { Severity } \\
(28 D A 3 T P)\end{array}$ & AUDPC & EFCD \% & $\begin{array}{c}\text { Incidence } \\
(21 D A 3 T P) \%\end{array}$ & $\begin{array}{c}\text { Incidence } \\
(28 D A 3 T P) \%\end{array}$ \\
\hline 1 & $5.26^{\mathrm{b}}$ & $40.13^{\mathrm{e}}$ & $177.29^{\mathrm{d}}$ & $0.00^{\mathrm{d}}$ & $84.99^{\mathrm{d}}$ & 100 \\
2 & $0.07^{\mathrm{a}}$ & $4.91^{\mathrm{a}}$ & $17.72^{\mathrm{a}}$ & $87.50^{\mathrm{a}}$ & $39.99^{\mathrm{b}}$ & 100 \\
3 & $0.13^{\mathrm{a}}$ & $6.25^{\mathrm{c}}$ & $22.83^{\mathrm{b}}$ & $85.00^{\mathrm{b}}$ & $39.16^{\mathrm{b}}$ & 100 \\
4 & $0.15^{\mathrm{a}}$ & $7.59^{\mathrm{d}}$ & $27.62^{\mathrm{c}}$ & $81.25^{\mathrm{c}}$ & $54.99^{\mathrm{c}}$ & 100 \\
5 & $0.10^{\mathrm{a}}$ & $5.53^{\mathrm{b}}$ & $20.12^{\mathrm{b}}$ & $85.62^{\mathrm{b}}$ & $50.83^{\mathrm{c}}$ & 100 \\
6 & $0.03^{\mathrm{a}}$ & $5.04^{\mathrm{a}}$ & $17.83^{\mathrm{a}}$ & $87.50^{\mathrm{a}}$ & $33.33^{\mathrm{a}}$ & 100 \\
7 & $0.12^{\mathrm{a}}$ & $7.63^{\mathrm{d}}$ & $27.56^{\mathrm{c}}$ & $80.62^{\mathrm{c}}$ & $52.49^{\mathrm{c}}$ & 100 \\
\hline $\mathrm{F}$ & 244.15 & 11312.79 & 4044.54 & & 78.135 & \\
$\mathrm{CV}(\%)$ & 29.75 & 2.2 & 4.16 & & 7.6 & \\
\hline
\end{tabular}

ASR symptoms could be seen from the third evaluation on, 21 DA3TP of the proposed control protocol. The rust severity was statistically higher in the control block, $5.26 \%$, while the average severity in the plants submitted to the treatments was $0.102 \%$. Regarding Asian rust severity, all the proposed treatments were lower when compared to the control treatment; however, the Fusão ${ }^{\circledR} /$ Aproach Prima ${ }^{\circledR} /$ Sphere Max ${ }^{\circledR}$ treatment obtained the worst scores among the fungicides, and this protocol was less effective to control P. pachyrhizi within the proposed program. Different results for disease severity in controls, but similar ones for fungicide mixtures were obtained by Barros et al. (2008), who observed disease severity 
ranging from 2.8 with fungicide application (11 to $25 \%$ infected leaf area) to 5 (infected leaf area of 75 to $100 \%$ ) in the control with no fungicides application. However, there was a significant reduction in ASR severity in treatments with fungicides mixtures (pyraclostobin + epoxiconazole), ranging from 0.06 to 0.56 , which indicates the absence of leaf symptoms when the mixtures was applied three times.

The meteorological conditions that favored $C$. truncatum development were the same ones for $P$. pachyrhizi development of. Thus, it was possible to analyze visually that $P$. pachyrhizi symptoms increased during the fourth evaluation ( 28 days) after the last fungicide application. The control plants had an index of $40.13 \%$ of severity, while the treatments with fungicides allowed the advance of the disease only to $6.16 \%$. Coincidentally, the onset of $P$. pachyrhizi symptoms occurred during the same period when $C$. truncatum symptoms were no longer visible and Asian rust may have prevented anthracnose population growth in the middle third and higher levels of the soybean plants.

Statistical analysis indicated that the area under the progression curve (AUDPC) of $P$. pachyrhizi obtained lower values in the treatments, when compared with the control. Fusão ${ }^{\circledR} /$ Aproach Prima ${ }^{\circledR} /$ Sphere Max ${ }^{\circledR}$ and Fox ${ }^{\circledR} /$ Orkestra ${ }^{\circledR} /$ Aproach Prima ${ }^{\circledR}$ treatments obtained similar results in AUDPC, with very high scores and low performance in the control and efficiency of $81.25 \%$ and $80.62 \%$, respectively. Fox ${ }^{\circledR} /$ Aproach Prima ${ }^{\circledR} /$ Sphere Max $^{\circledR}$ treatment yielded medium results for AUDPC and rust control performance, resembling Elatus ${ }^{\circledR} /$ Aproach Prima ${ }^{\circledR} /$ Sphere Max $^{\circledR}$. The treatments that obtained the best result with low AUDPC scores and greater efficiency for $P$. pachyrhizi control were Orkestra ${ }^{\circledR} /$ Fox $^{\circledR} /$ Aproach Prima ${ }^{\circledR}$ and Orkestra ${ }^{\circledR} /$ Aproach Prima ${ }^{\circledR} /$ Sphere Max ${ }^{\circledR}$, both with an efficiency average of $87.5 \%$. These results corroborate the study by Sacon et al. (2018) in which all the treatments presented control above $80 \%$ after three applications of the fungicide mixture (tebuconazol + picoxystrobin), reaching $96 \%$ of control after five applications for BMX Tornado cultivar.

The incidence of rust was evaluated in all proposed treatments, with symptom absence during the first evaluations prior to each fungicide application and during two 7DA3TP and 14DA3TP evaluations. It is important to emphasize that the applications were carried out in a preventive way, anticipating the rust infestation period or before the symptom manifestation period. The Orkestra ${ }^{\circledR} /$ Fox $^{\circledR} /$ Aproach Prima ${ }^{\circledR}$ treatment maintained the highest level of control in relation to the other treatments, regarding this (Table 3). In the study developed by Sacon et al. (2018), the onset of ASR severity in cultivars treated with three applications of fungicide mixture was also verified in the third week after disease onset. In the cited study, the required amount of applications for effective ASR control was measured, and did not show significant differences between the treatments with three, four and five applications, during five evaluations, keeping a final severity percentage below $19 \%$ for BMX Tornado cultivar and $11 \%$ for TMG 7232 cultivar.

\subsection{Productivity}

The grain productivity in $\mathrm{kg} \mathrm{ha}^{-1}$ was converted into bags $\mathrm{ha}^{-1}$, and the result of productivity increase was measured in relation to the average productivity obtained by the control. 


\section{Mll Macrothink}

Treatment 1 (control), which was submitted only to pest and weed control, obtained an average yield of 49.5 bags ha $^{-1}$. The Orkestra ${ }^{\circledR} /$ Aproach Prima ${ }^{\circledR} /$ Sphere Max $^{\circledR}$ treatment obtained the best average productivity of the proposed protocol for Phakopsora pachyrhizi and Colletotrichum truncatum control , 66 bags ha $^{-1}$, that is, $33.33 \%$ more than the control, while the lowest productivity was the Fox ${ }^{\circledR} /$ Orkestra ${ }^{\circledR} /$ Aproach Prima ${ }^{\circledR}$ treatment, which had 56.75 bags $\mathrm{ha}^{-1}$, a total of $14.64 \%$ more than the control. The treatment Orkestra ${ }^{\circledR} /$ Fox $^{\circledR} /$ Aproach Prima ${ }^{\circledR}$ obtained a better result than the treatment reported above, 59.00 bags ha $^{-1}$. Thus, it obtained 2.25 more bags than the treatment initiated with Fox ${ }^{\circledR}$ and sequential application of a carboxamide (Orkestra ${ }^{\circledR}$ ) and $19.19 \%$ more than the control.

The use of fungicides to control diseases evaluated in this study are extremely important and has not been reported only by us. Sacon et al. (2018), in their study, obtained a yield increase of $48 \%$ using three fungicide applications compared to the control for BMX Tornado cultivar and $22.72 \%$ for TMG 7232 cultivar. The same authors achieved a productivity increase of up to $57 \%$ for TMG 7232 using 5 fungicide applications. Barros et al. (2008) also showed an increase in productivity compared to the control of both cultivars (Vencedora and Conquista) treated with 3 fungicide applications. Therefore, it is emphasized that a strict control with sequential applications increases the producer's gains and decreases soybean losses during the cultivation of this commodity.

According to the research conducted with the local market, the Cooperatives, Cereal, Agribusiness and Resellers in the region of Assis Chateaubriand, the final average values of each product used in the proposed disease control treatment were: Orkestra ${ }^{\circledR}$ : USD 92.27/liter; Aproach Prima $^{\circledR}$ : USD 42.00/liter; Sphere Max ${ }^{\circledR}$ : USD 67/liter; Fusão ${ }^{\circledR}$ : USD 35.47/liter; Elatus $^{\circledR}$ : USD $118 / \mathrm{Kg}$ and Fox ${ }^{\circledR}$ : USD $65.00 /$ liter. The amounts were converted from Brazilian Real (R\$) to USD and updated according to Google Finance data in May 2019.

A relationship between the average obtained yield per treatment, and the cost for the completion of each application was done, considering only the values of the product, relieving any operating cost and using the baseline value for soybean bag at USD 20.00. It is possible to verify that the value of each set of applications varied from USD 47.00 to USD 71.46. (Table 4).

Table 4. Cost-benefit of fungicides evaluated among treatments for control of Anthracnosis and Asian Rust

\begin{tabular}{ccccc}
\hline Treatment & $\begin{array}{c}\text { Application end } \\
\text { value }\end{array}$ & Cost bag ha ${ }^{-1}$ & $\begin{array}{c}\text { Soybean } \\
\text { Yield bag }\end{array}$ & $\begin{array}{c}\text { Net productivity in } \\
\text { relation to the } \\
\text { control }\end{array}$ \\
\hline 2 & USD 58.42 & USD 0.75 & 16.5 & 13.55 \\
3 & USD 52.65 & USD 0.65 & 8.5 & 5.88 \\
4 & USD 47.39 & USD 0.59 & 9 & 6.64 \\
5 & USD 50.15 & USD 0.62 & 8.5 & 6.00 \\
6 & USD 71.46 & USD 0.89 & 9.5 & 5.94 \\
7 & USD 71.46 & USD 0.89 & 7.25 & 3.69 \\
\hline
\end{tabular}


The most significant cost-benefit treatment was with Orkestra ${ }^{\circledR} /$ Aproach Prima ${ }^{\circledR} /$ Sphere $\mathrm{Max}^{\circledR}$, costing $2.92 \mathrm{bags} \mathrm{ha}^{-1}$ and net productivity compared to the control of $13.57 \mathrm{bags} \mathrm{ha}^{-1}$, according to Table 4. The treatment that obtained the lowest cost $\mathrm{x}$ benefit was Fox ${ }^{\circledR} /$ Orkestra ${ }^{\circledR} /$ Aproach Prima ${ }^{\circledR}$, with a cost of 3.55 bags ha $^{-1}$ and net productivity in relation to the control of 3.69 bags ha $^{-1}$.

Thus, taking into account the data presented in this research, we suggest the Orkestra ${ }^{\circledR} /$ Aproach Prima ${ }^{\circledR} /$ Sphere Max ${ }^{\circledR}$ treatment for the control of Phakopsora pachyrhizi and Colletotrichum truncatum in soybean.

\section{Conclusion}

Regarding Anthracnose disease, all evaluated treatments presented lower severity when compared with the control. However, the treatment Elatus ${ }^{\circledR} /$ Aproach Prima ${ }^{\circledR} /$ Sphere Max $^{\circledR}$ obtained the worst score among fungicides. Concerning the values of AUDPC, the treatment Orkestra $^{\circledR} /$ Fox $^{\circledR} /$ Aproach Prima ${ }^{\circledR}$ presented the lower values and better control of Colletotrichum truncatum, followed by Orkestra ${ }^{\circledR} /$ Aproach Prima ${ }^{\circledR} /$ Sphere Max ${ }^{\circledR}$.

In relation to Asian rust disease, all the proposed treatments presented lower severity compared to the control treatment, but the treatment Fusão ${ }^{\circledR} /$ Aproach Prima ${ }^{\circledR} /$ Sphere Max ${ }^{\circledR}$ obtained the worst scores among all the evaluated treatments. Regarding the AUDPC values, the treatments Orkestra ${ }^{\circledR} /$ Fox $^{\circledR} /$ Aproach Prima ${ }^{\circledR}$ and Orkestra ${ }^{\circledR} /$ Aproach Prima ${ }^{\circledR} /$ Sphere $\mathrm{Max}^{\circledR}$ obtained the best results, with the lowest scores, both with an efficiency average of $87.5 \%$.

The protocol Orkestra ${ }^{\circledR} /$ Aproach Prima ${ }^{\circledR} /$ Sphere Max $^{\circledR}$ was the most significant cost-benefit treatment in this study, which we suggest to be used for the control of Phakopsora pachyrhizi e Colletotrichum truncatum.

\section{References}

Abbott, W. S. (1925). A method of computing the effectiveness of an insecticide. Journal of Economic Entomology, 18, 265-267. https://doi.org/10.1093/jee/18.2.265a

Adami, P., Santos, I., Franchin, M., Sartor, L., Tartaro, D., Nunes, E., \& Xavier, F. (2006). Eficiência de fungicidas no controle da antracnose (Colletotrichum dematium var. truncata) da soja (Glicine max). Sinergismus Scyentifica UTFPR, 1, 22-28.

Alves, V. M., \& Juliatti, F. C. (2018). Fungicides in the management of soybean rust, physiological processes and crop productivity. Summa Phytopathologica, 44(3), 245-251. https://dx.doi.org/10.1590/0100-5405/167203

Balardin, R. S., Madalosso, M. G., Stefanello, M. T., Marques, L. N., \& Debortoli, M. P. (2017). Mancozebe - Muito além de um fungicida. n. 1. Porto Alegre: Bookman.

Barros, H. B., Sediyama, T., Reis, M. S., \& Cecon, P. R. (2008). Efeito do número de aplicação de fungicida no controle da ferrugem da soja. Acta Scientiarum Agronomy, 30, 239-245. https://doi.org/10.4025/actasciagron.v30i2.1741 
Basso, P., Bonaldo, S. M., \& Ruffato, S. (2015). Avalição de fungicidas no controle de antracnose e mancha alvo, e no rendimento da cultura da soja. Scientia Agraria Paranaensis, 14, 191-199. https://doi.org/10.18188/1983-1471/sap.v14n3p191-199

Campbell, C. L., \& Madden, L. V. (1990). Introduction to plant disease epidemiology. n. 1. New Jersey: John Wiley, 590 p.

Dias, M. D., Pinheiro, V. F., \& Café-Filho, A. C. (2016). Impact of anthracnose on the yield of soybean subjected to chemical control in the north region of Brazil. Summa Phytopathologica, 42, 18 -23. https://doi.org/10.1590/0100-5405/2114

Doringhello, D. V., Bettiol, W., Maia, B. N., \& Leite, M. V. B. C. (2015). Controlling Asian soybean rust (Phakopsora pachyrhizi) with Bacillus spp. And coffe oil. Crop protection, 67, 59-65. https://oi.org/10.1016/j.cropro.2014.09.017

FAO (2019, March 25). In: Faostat - Statistics Database. 2019. Retrieved March 25, 2019, from http://www.fao.org/faostat

FRAC-Fungicide Resistance Action Committee (2018). Retrieved from http://www.frac-br.org

Godoy, C. V., Koga, L. J., \& Canteri, M. G. (2006). Escala diagramática para avaliação da severidade da ferrugem da soja. Fitopatologia brasileira, 31, 63-68. https://doi.org/10.1590/s0100-41582006000100011

Goellner, K., Loehrer, M., Langenbach, C., Conrath, U., Koch, E., \& Schaffrath, U. (2010). Phakopsora pachyrhizi, the causal agent of Asian soybean rust. Molecular Plant Pathology, 11, 169-177. https://doi.org/10.1111/j.1364-3703.2009.00589.x

Ito, M. F. (2013). Principais doenças da cultura da soja e manejo integrado. $1^{\circ}$ encontro técnico sobre as culturas da soja e do milho no noroeste paulista. Nucleous, 1, 83-102. https://doi.org/10.3738/nucleus.v0i0.908

Klosowski, A. C., De Mio, L. L. M., Miessner, S., Rodrigues, R., \& Stammler, G. (2016). Detection of the F129L mutation in the cytochrome b gene in Phakopsora pachyrhizi. Pest Management Science, 72, 1211-1215. https://doi.org/10.1002/ps.4099

Koenning, S. R., \& Wrather J. A. (2010). Suppression of soybean yield potential in the continental United States by plant diseases from 2006 to 2009. Plant Health Progress, 11, 1-6. https://doi.org/10.1094/PHP-2010-1122-01-RS

Moura, B., Boller, W., \& Deuner, C. C. (2016). In vitro determination of fungicide inhibitory concentration for Phakopsora pachyrhizi isolates. Summa Phytopathologica, 42, 170-171. https://doi.org/10.1590/0100-5405/2097

Pesqueira, A. S., Bacchi, L. M. A., \& Gavassoni, W. L. (2016). Associação de fungicidas no controle da antracnose da soja no Mato Grosso do Sul. Revista Ciência Agronômica, 47, 203-212. https://doi.org/10.5935/1806-6690.20160024 


\section{Macrothink}

Journal of Agricultural Studies

ISSN 2166-0379

2019, Vol. 7, No. 4

Reis, E. M., Silva, L. H. C. P., Siqueri, F. V., \& Silva, J. R. C. (2014). Evolução da reduçâo da sensibilidade de Phakopsora pachyrhizi a fungicidas e estratégias para recuperar a eficiência de controle. n.3. Passo Fundo: Berthier.

Rodrigues, F. A., Duarte, H. S. S., Domiciano, G. P., Souza, C. A., Korndorfer, G. H., \& Zambolim, L. (2009). Foliar application of potassium silicate reduces the intensity of soybean rust. Australasian Plant Pathology, 38, 366-372. https://doi.org/10.1071/AP09010

Rossi, R. L. (2003). First report of Phakopsora pachyrhizi, the causal organism of soybean rust in the province of Misiones, Argentina. Plant Disease, 87, 102-107.

https://doi.org/10.1094/PDIS.2003.87.1.102A

Sacon, D., Netto, A., Tonell, E. S., Fochesatto, M., Tortelli, B., \& Milanesi, P. M (2018). Número de aplicações de fungicida e comparação entre cultivares com e sem tolerância no controle da ferrugem asiática da soja. Acta Iguazu, 7, 47-58.

Scott, A. J., \& Knott, M. A. (1974). A cluster analyses method for grouping means in the analyses of variance. Biometrics, 30, 507-512. https://doi.org/10.2307/2529204

Sharma, S. K., Gupta, G. K., \& Ramteke, R. (2011). Colletotrichum truncatum [(Schw.) Andrus \& W.D. Moore], the Causal Agent of Anthracnose of Soybean [Glycine max (L.) Merrill] - A review. In: Soybean research, 9, Madhya Pradesh. India: O. P. Joshi, p. 31-52.

Yang, H. C., \& Hartman, G. L. (2015). Methods and evaluation of soybean genotypes for resistance to Colletotrichum truncatum. Plant Disease, 99, 143-148.

https://doi.org/10.1094/PDIS-03-14-0228-RE

Yorinori, J. T., Paiva, W. M., Frederick, R. D., Costamilan, L. M., Bertagnolli, P. F., Hartman, ... Nunes Junior, J. (2005). Epidemics of soybean rust (Phakopsora pachyrhizi) in Brazil and Paraguay from 2001 to 2003. Plant Disease, 89, 675-677.

https://doi.org/10.1094/PD-89-0675.

\section{Copyright Disclaimer}

Copyright for this article is retained by the author(s), with first publication rights granted to the journal.

This is an open-access article distributed under the terms and conditions of the Creative Commons Attribution license (http://creativecommons.org/licenses/by/4.0/). 